Kong. Res. J. 2(1) : 105-110, 2015

ISSN 2349-2694

Kongunadu Arts and Science College, Coimbatore.

\title{
ESTIMATION OF MICROBIAL BURDEN DUE TO DIFFUSED AND POINT SOURCES AT SPATIAL SCALE IN MIDDLE STRETCH OF RIVER BHAVANI, COIMBATORE, TAMILNADU
}

\author{
Nithya Jeniffer, $\mathrm{P}^{1 *}$,, and Manish Kumar ${ }^{2}$, and K. Logan Kumar ${ }^{3}$ \\ ${ }^{1} \mathrm{PG}$ and Research Department of Zoology, Nirmala College for Women, Red fields Coimbatore - 641029. \\ ${ }^{2}$ Environmental Impact Assessment Division, Sálim Ali Centre for Ornithology and \\ Natural History (SACON), Anaikatti (PO), Coimbatore - 641108 \\ ${ }^{3} \mathrm{PG}$ and Research Department of Zoology, Kongunadu Arts and Science College, Coimbatore - 641029. \\ *E-mail: jenii@rediffmailcom
}

\begin{abstract}
This study was aimed to estimate the microbiological status of river Bhavani which is the major life line of the surrounding area. The river water is used mainly for drinking, washing and swimming purposes. Water samples were collected from five sites (Pilloor, Effluent, Sweage I \& II, Bhavanisagar reservoir) and the results obtained were compared with WHO and EP standards for drinking and recreational water. In the present investigation station III and IV (which is Sweage I \& II respective points) showed more numbers of microbes were present which cause the deadly diseases to human being as well as in aquatic, terrestrial organism due the sewage discharges from the nearby towns. But in the case of lower stream (Bhavanisagar reservoir) that the counts of microorganism present in the reservoir was slightly reduced. The major groups of microorganisms were isolated and identified are E. coli, P. aerugionosa, E. aerogenes, S. aureus, Salmonella $s p$, Bacillus sp, Proteus sp, Klebsiella sp, Flavo bacterium, Acinetobacter sp. The results are alarming and show that alternative measures to reduce the pollution should be taken in favor of society.
\end{abstract}

Key words: Microbial pollution, river Bhavani, Bhavanisagar reservoir, Effluent, Pilloor reservoir

\section{INTRODUCTION}

Fresh water resources are becoming deteriorated day-by-day at a very faster rate. Now water quality is a global problem (Mahananda et al., 2005). Water is a resource that has many uses, including recreation, transportation, and hydroelectric power, domestic, industrial and commercial uses. Water also supports all forms of life and affects our health, lifestyle, and economic wellbeing. Although more than three quarters of the earth's surface is made up of water, only 2.8 percent of the earth's water is available for human consumption (Iskandar, 2010). Water is available in the universe in huge quantity in the order of $1400 \mathrm{x}$ $106 \mathrm{~km}^{3}$ and only $3 \%$ of the waters in the universe as freshwater. Among the freshwaters, only about $5 \%$ of them or $0.15 \%$ of the total world waters are readily available for beneficial use. The total water resource available in India is $1850 \mathrm{~km}^{3}$, which is roughly $4 \%$ of the world's fresh water resources. Water can be obtained from a number of sources, among which are streams, lakes, rivers, ponds, rain, springs and wells. Rivers are vital and vulnerable freshwater systems that are critical for the sustenance of all life. However, the declining quality of the water in these systems threatens their sustainability and is therefore a cause for concern. Rivers are waterways of strategic importance across the world, providing main water resources for domestic, industrial, and agricultural purposes (Fathi, 2006). Rivers play a major role in assimilation or carrying off of municipal and industrial wastewater and runoff from agricultural land, the former constitutes the constant polluting source whereas the later is a seasonal phenomenon.

Pollution of river in India has now reached to a point of crisis due to unplanned urbanization and rapid growth of industrialization. Waste comprises liquid waste discharged by domestic residences, commercial properties, industry or agriculture and can encompass a wide range of potential contaminants and concentrations. Discharge of organic wastes human excreta, sewage waste, polythenes, municipal garbage and toxic discharge from the factories increasing bacterial pollution. These wastes flow into the storm drains, mixing with common water and subsequently posing a serious threat to the water ecology, animal and human society.

In the most common usage, it refers to the municipal wastewater that contains a broad spectrum of contaminants resulting from the mixing 
of wastewater from different sources. Sewage is created by residences, institutions, hospitals and commercial and industrial establishments (APHA, 1998). Raw influent includes household waste liquid from toilets, baths, showers, kitchens, sinks, and so forth that is disposed of via sewers. In many areas, sewage also includes liquid waste from industry and commerce. As rainfall runs over the surface of roofs and the ground, it may pick up various contaminants including soil particles and other sediment, heavy metals, organic compounds animal waste and oil and grease (FWPCA, 1998). Consequently, the problem was taken up when effluents of these industries go into the water system and change the physicochemical quality of water and make it unfit for drinking and other uses. This effect of water pollution results in transmission of infectious diseases such as cholera, diarrhoea and typhoid (FWPCA, 1998).

Microorganisms are widely distributed in nature and diversity of microorganisms may be used as an indicator for organic pollution (Okpokwasili and Akujobi, 1996). Bacteriological quality of drinking water usually shows concentration of particular species of bacteria and their occurrence (Sandy and Richard, 1995). Cryptosporidiosis, typhoid fever, Cholera, dysentery and hepatitis are some of the common waterborne diseases that spread through contaminated water. Contaminated water can cause eye, ear, nose and throat infections also.

Bacteriological examination offers the most sensitive test for the detection of recent and therefore potentially dangerous faecal pollution thereby providing a hygienic assessment of water quality with a sensitivity and specificity that is absent from routine chemical analysis. It is essential that water is examined regularly and frequently as contamination may be intermittent and may not be detected by the examination of a single sample. For this reason, it is important that drinking water is examined frequently (Mane, 2005).

\section{MATERIALS AND METHODS}

\subsection{Description of the study area}

River Bhavani is one of the major tributaries of the river Cauvery originated from Western Ghat region, Nilgiris biosphere, and second largest river in Tamilnadu. It crosses the distance of about $217 \mathrm{~km}$ through Mettupalayam and Sirumugai before merging with Cauvery spread over Tamil Nadu (87\%), Kerala (9\%) and Karnataka (4\%). About 90 percent of the river water is used for irrigation, culturing of fishes, drinking purposes and hydroelectric power. Around six million people are directly or indirectly depending and living along its banks. The study area divided in a broad sense in three parts namely upper stream (station I, Pilloor reservoir), middle stream (station II, effluent mixing point; station III, sewage 1 , station IV sewage mixing point 2) and downstream (station V, Bhavanisagar reservoir) and water samples were collected aseptically and transported to the laboratory for analysis the rapid survey was carried our between 2011-12 session to estimate the microbial load and possible impacts of microorganisms on the people receiving end.

Pilloor reservoir (N $11.27^{\circ} \&$ E $\left.76.80^{\circ}\right)$ located on River Bhavani, $88 \mathrm{~m}$ high has a catchment area of $1,191 \mathrm{~km}^{2}$; the dam is $357 \mathrm{~m}$ long and the mean annual flow is $685 \mathrm{MCM}$. Mettupalayam $\left(11.30^{\circ} \mathrm{N} \&\right.$ $76.95^{\circ} \mathrm{E}$ ) is situated on the bank of Bhavani River at the foot of the Nilgiri hills. It has an average elevation of 314 meters (1033 feet). The Bhavanisagar reserviour $\left(11^{\circ} 26^{\prime} 45.09^{\prime \prime} \mathrm{N}, 77^{\circ} 4^{\prime}\right.$ 25.37" E) is located in Bhavanaisagar at $50 \mathrm{Km}$ North East from Mettupalayam city, Tamilnadu. It is the longest earthen reservoir of its kind in Tamilnadu state measuring $8780 \mathrm{mt}$ and ranking second largest reservoir with a capacity of 929 million cubic meters; the total catchment area is1621.50 Sq. miles.

At Mettupalayam, numerous slaughter houses, domestic sewage, dyeing and United Bleaching factory (UBL) effluents mix with river Bhavani. Numerous industries are located along the stretch of river causing severe environmental pollution and ecological imbalance to the river.

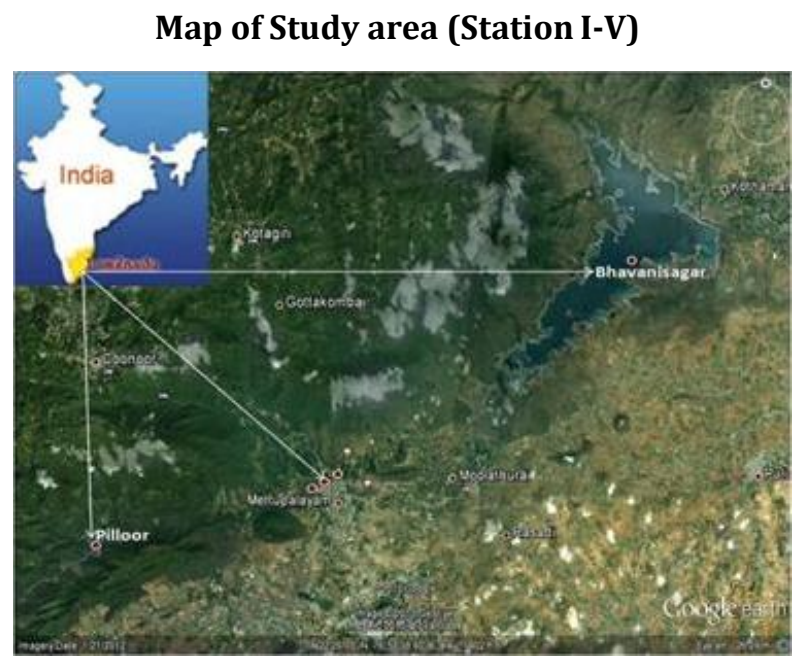

\subsection{Media used and their preparation}

The media used for this present analysis are given in below. All the media were prepared according to the manufacturer's instruction and 
adequately sterilized in an autoclave at $121^{\circ} \mathrm{C}$ for 15 min.

\begin{tabular}{ll}
\hline \multicolumn{1}{c}{ Media used } & \multicolumn{1}{c}{ Remarks } \\
\hline Nutrient Agar (NA) & For isolation of gram negative \\
Eosine Methylene Blue (EMB) & $\begin{array}{l}\text { bacteria and screens them } \\
\text { MacConkey broth }\end{array}$ \\
$\begin{array}{l}\text { Sugars like glucose, mannitol, } \\
\text { lactose, fructose and galactose } \\
\text { Indole Ornithine fluid media }\end{array}$ & For fermentation test \\
\hline
\end{tabular}

\subsection{Enumeration and detection of bacteria}

The aliquot of the specimens to be cultured was placed in the bottom of an empty, sterile petri dish and melted and cooled agar was poured over it. The plate was swapped to allow proper mixing. The agar was allowed to gel (solidified) after which the plate was incubated in an incubator at $37^{\circ} \mathrm{C}$ for $24 \mathrm{~h}$. Subculturing of isolates and stock cultures Nutrient Agar (NA) was poured aseptically into plates and allowed to solidify Specific colonies on the samples. When primary isolation of the plates has been properly streaked, individual colonies was picked and incubated on fresh NA. Subsequent sub-culturing was carried out until pure cultures of the different isolates were obtained. These pure isolates were transferred onto agar slants in McCartney bottles and kept in the refrigerator as stock culture for subsequent tests during identification.

\subsection{Total plate counts}

The heterotrophic plate count (HPC)/total count was carried out to provide an estimate of the total number of bacteria in each of the samples that would develop into colonies during the period of incubation on Nutrient Agar and Eosine methylene blue agar plates. This test detects a broad group of bacteria including the pathogens, nonpathogenic and opportunistic pathogens. The laboratory procedure involves making serial dilution of the sample in sterile distilled water and cultivating $10^{-3}$ and $10^{-5}$ then $10^{\circ}$ and $10^{-2}$ dilution factor into the center of petri dish. The prepared media were allowed to cool to about $40^{\circ} \mathrm{C}$ before they were added to the dilution factors. The plates were incubated at $37^{\circ} \mathrm{C}$ for $24 \mathrm{~h}$ in inverted position to prevent condensation from the lid to the agar, after which the number of the colonies formed was counted. The acceptable value of the total number of Colony Forming Units (CFU) during the plate count for potable water was a total of less than $102 / \mathrm{ml}$.

\subsection{Coliform count}

Most probable number (MPN) method: This was done as recommended by standard method
(APHA, 1998). The materials and media used for the analysis consisted of fermentation tubes with aluminum caps, Durham tubes, MacConkey Broth (Single and double strength) inoculating loop,

Bunsen burner and syringes (10, 5 and $2 \mathrm{ml})$. The most probable number tube fermentation technique is performed in three stages: Presumptive test, confirmative test and completed test.

\subsection{Biochemical tests and identification of microbial isolates}

Morphological and biochemical characteristics of the microbial isolates were used for the identification of the isolates according to Baron et al. (1990), Benson (1990) and Bitton (1994). The Bergey's Manual of determinative bacteriology by Buchanan and Gibbons (1974) was used to compare the characteristics with the results obtained.

\section{RESULTS}

The public health significance of water quality cannot be over emphasized. Many infectious diseases are transmitted by water through the fecaloral route. In human health, water has a profound influence and quality of the water supplied is important in determining the health of individuals and whole communities.

The quality of river water was deteriorated by the presence of bacterial population. In the present study microorganisms were analyzed in the following stations of Pilloor reservoir, effluent mixing point, sewage I, sewage II and Bhavanisagar reservoir. The viable counts for all water samples were quite high.

The mean Total bacterial count of different water samples are Pilloor reservoir (25X10-6 CFU), effluent mixing point ( $\left.45 \mathrm{X} 10^{-6} \mathrm{CFU}\right)$, sewage I (70 $\left.\mathrm{X} 10^{-6} \mathrm{CFU}\right)$, sewage II (65X10-6 CFU), Bhavanisagar reservoir (53X10-6 $\mathrm{CFU})$. But in station III and IV the total bacterial count found to be higher when comparing to other stations.

Comparing the results with (WHO, 1993) the sewage mixing point I and II are highly contaminated, and also denotes the potential public health hazards. In the present study station III (sewage II) shows the maximum 24\% of TBC (total bacterial count) and in the case of TC (total coliform) station II showed the maximum $27 \%$. Various groups of microorganisms were isolated and identified are E. coli, P. aerugionosa, E. aerogenes, S. aureus, Salmonella $s p$, Bacillus sp, Proteus sp, Klebsiella sp, Flavo bacterium, Acinetobacter sp. 
Table 1. Morphological Characteristics of identified microorganisms present in river Bhavani at different sampling sites.

\begin{tabular}{|c|c|c|}
\hline S.No & Morphological Characteristics & Identified micro organism \\
\hline 1 & $\begin{array}{l}\text { Non-spore forming and non-motile, Gram positive cocci, circular, low convex with entire } \\
\text { margin, smooth, medium, opaque, golden yellow colony on Nutrient Agar, grown at } \mathrm{pH} 7 \text { and } \\
37^{\circ} \mathrm{C}\end{array}$ & S. aureus \\
\hline 2 & $\begin{array}{l}\text { Dark centered, gram negative, non endospores forming colony on Salmonella-Shigella Agar } \\
\text { Gram negative, circular, low convex, with entire margin, mucoid, opaque, small, non }\end{array}$ & Salmonella sp. \\
\hline 3 & $\begin{array}{l}\text { endospores forming rod shaped, pinkish glistering with metallic sheen colony on Eosin } \\
\text { Methylene Blue (EMB) Agar; grown at pH 7, 37and 450C. }\end{array}$ & E. coli \\
\hline 4 & $\begin{array}{l}\text { Non-spore forming, Gram negative short rods, colourless colony on Nutrient Agar, grown at } \\
\text { 4and 42OC }\end{array}$ & P. aerugionosa \\
\hline 5 & Gram negative, non endospores forming rod, light-yellow colony withfeather-like margin. & E. aerogenes \\
\hline 6 & Spore forming, Gram positive rods, creamy white colony on Nutrient Agar with entire margin & Bacillus sp. \\
\hline 7 & $\begin{array}{l}\text { Non-spore forming and non-motile gram negative rod colony on Nutrient Agar that appeared } \\
\text { translucent with serrated or feather-like margins }\end{array}$ & Proteus sp \\
\hline 8 & Gram negative rods on Nutrient Agar & Klebsiella sp \\
\hline 9 & Gram negative rods that appeared yellowish with entire margin on Nutrient Agar & \\
\hline 10 & Gram positive rod that appear grey-white with undulated marginon Nutrient Agar & $\begin{array}{l}\text { sp. } \\
\text { Acinetobacter sp. }\end{array}$ \\
\hline
\end{tabular}

Table 2: Total bacterial and coliform counts of water samples in river Bhavani.

\begin{tabular}{|c|c|c|c|c|}
\hline \multirow[t]{2}{*}{ Sample source } & \multicolumn{2}{|c|}{$\begin{array}{c}\text { Total bacterial } \\
\text { count }\end{array}$} & \multicolumn{2}{|c|}{$\begin{array}{l}\text { Total coli form } \\
\text { counts }\end{array}$} \\
\hline & $\begin{array}{c}\text { CFU } \\
\mathrm{X10}^{-6} \mathrm{ml} \\
\end{array}$ & $\begin{array}{c}\text { CFU } \\
\times 10^{-7} \mathrm{ml}\end{array}$ & $\begin{array}{c}\text { CFU X10 } \\
{ }^{6} \mathrm{ml}\end{array}$ & $\begin{array}{c}\text { CFU X10 } \\
{ }^{7} \mathrm{ml}\end{array}$ \\
\hline Pillur reservoir & 25 & 16 & 10 & 8 \\
\hline Effluent & 45 & 12 & 34 & 12 \\
\hline Sewage I & 70 & 25 & 48 & 30 \\
\hline Sewage II & 65 & 22 & 45 & 25 \\
\hline $\begin{array}{l}\text { Bhavanisagar } \\
\text { reservoir }\end{array}$ & 53 & 18 & 38 & 10 \\
\hline
\end{tabular}

Table 3: Isolated microorganisms from different water samples of river Bhavani

\begin{tabular}{|c|c|c|c|c|c|}
\hline $\begin{array}{c}\begin{array}{c}\text { Identified } \\
\text { microorgan } \\
\text { ism }\end{array} \\
\end{array}$ & $\begin{array}{c}\text { Pillur } \\
\text { reserv } \\
\text { oir }\end{array}$ & $\begin{array}{c}\text { Efflue } \\
\text { nt }\end{array}$ & $\begin{array}{c}\text { Sewa } \\
\text { ge I }\end{array}$ & $\begin{array}{c}\text { Sewa } \\
\text { ge II }\end{array}$ & $\begin{array}{c}\text { Bhavanisa } \\
\text { gar } \\
\text { reservoir }\end{array}$ \\
\hline $\begin{array}{l}\text { Echerichia } \\
\text { coli }\end{array}$ & - & + & + & + & + \\
\hline $\begin{array}{l}\text { Pseudomona } \\
\text { s sp }\end{array}$ & + & + & + & + & + \\
\hline $\begin{array}{l}\text { Enterobacte } \\
\text { r aerogenes }\end{array}$ & + & + & + & + & + \\
\hline $\begin{array}{l}\text { Salmonella } \\
s p\end{array}$ & - & + & + & + & + \\
\hline S. aureus & - & + & + & + & + \\
\hline $\begin{array}{l}\text { Flavobacteri } \\
\text { um }\end{array}$ & - & + & + & + & + \\
\hline Proteus sp & + & + & + & + & + \\
\hline Klebsiella sp & + & + & + & + & + \\
\hline $\begin{array}{l}\text { Acinetobact } \\
\text { er sp. }\end{array}$ & + & + & + & + & + \\
\hline $\begin{array}{l}\text { Bacillus } \\
\text { subtills }\end{array}$ & + & + & + & + & + \\
\hline
\end{tabular}

\section{DISCUSSION}

The assessment of microbiological quality of water from different sources was essential for detecting the presence or absence of organisms that might constitute health hazards in water, which could be used as a guide to monitor and protect the water sources. The total bacterial counts for all the samples were generally high, exceeding the limit of $1.0 \times 102 \mathrm{CFU} / \mathrm{ml}$ which was the standard limit of heterotrophic count for drinking water (EPA, 2002).

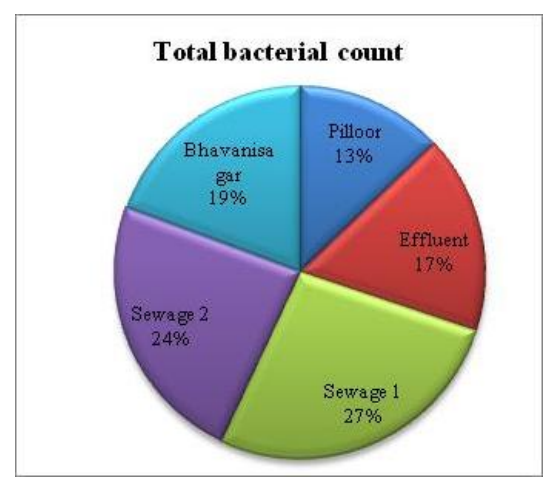

Fig. 1: Total bacterial count in different sampling stations of river Bhavani

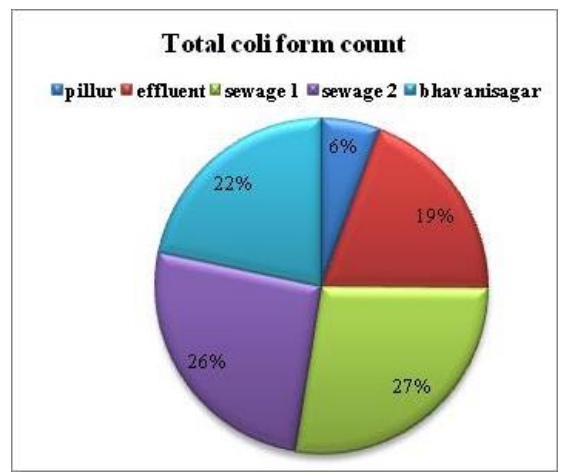

Fig. 2: Total coilform count in different sampling stations of river Bhavani

The reason for high number of bacterial colonies might be due to inadequate maintenance of reservoir water and the percolation of sewage into river (Krishnan, 2007). The high total plate counts observed in sewage water indicated the presence of 
high organic matters and related nutrient sources. The primary sources of bacterial contamination might include the surface runoff, sewage treatment facilities, natural soil/plants, bacteria and improper management activities of the inhabitants like washing, refuse dumpage, faecal droppings, dipping of different materials inside the water sources. These contaminants are reflected in the river water. Omezuruike et al. (2008) revealed that the original source of any drinking water is rich in aquatic microbes, some of which could be dangerous if they enter the human body.

The water samples from sewage point the total coliform were exceedingly high as against the EPA maximum contamination level (MCL) for coliform bacteria in drinking water of zero total coliform per $100 \mathrm{ml}$ of water (EPA, 2002). The high coliform count obtained in the samples may be an indication that the water sources were faecal contaminated (EPA, 2002; Osunide and Enuezie, 1999). The same results of the high number of total coliforms were observed in the Umian lake water in both pre monsoon and post monsoon seasons (Krishnan, 2007; Ajayi, 2011).

Various groups of microorganisms were isolated and identified during the study. They include Escherichia coli, Streptococcus sp., Enterobacter sp., Pseudomonas sp., $S$. aureus, Flavobacterium sp., Pseudomonas sp., Proteus sp., Klebsiella sp., and Bacillus sp. The presence of coliforms group in water samples generally suggests that a certain selection of water may have been contaminated with faeces either of human or animal origin (Richman, 1997).

\section{CONCLUSION}

River Bhavani is lifeline of the Tamilnadu which feeds the more than twelve thousands acre agricultural lands and supports the livelihoods of millions of peoples residing along the banks. The river water is mainly used for the drinking, irrigation, recreational and industrial uses. In India almost $70 \%$ of the water has become polluted due to the discharge of domestic sewage and industrial effluents into natural water source. The improper management of water systems may cause serious problems in availability and quality of water. The wastes discharge from sewage, industry, agriculture and anthropogenic activities are seriously polluting the water which promotes the growth of pathogenic microorganisms. Microbial examination of water is therefore a powerful and foremost tool in order to foreclose the presence of health hazard microorganisms. Commonly used indicators of water quality include Coliforms, faecal streptococci, Clostridium perfringes, and Pseudomonas aeroginosa etc. In the present study also these indicators are recorded in different concentration at different stations. The higher amount of microorganisms are found near more populous area and lowered in diminish. The continuous accumulation in down flow may create serious problem in future for stakeholders. So it is a high time to take the serious step regarding pretreatment of sewage and effluents, setup of STPs and ETPs in local levels, make awareness program regarding the wise use of water and its wastage, contaminants and future impacts on our health.

\section{REFERENCES}

Ajayi, 0. and T.O. Adejumo, (2011). Microbiological assessment and some physico-chemical properties of water sources in Akungba-Akoko, Nigeria. A. J. Toxi. and Envir. Heal. Scie. 3(13): 342-346.

American Public Health Associated (APHA). (1998). Standard method for examination of water and waste water, 20th ed. American Public Health Associated Inc, New York. American Water Work Associated (AWWA). Research Foundation, 1993. Bacterial examination of water. West Quincy Avenue Denver, p. 81-85.

Baron, J., M.F. Sydney, (1990). Bailey and Scott's Diagnostic Microbiology. The C.V. Mosby Co., St. Louis, p. 861

Benson, H.J. (1990). Microbiological Applications: A Laboratory Manual in General Microbiology. Wm, C, Brown Publishers, Dubuque, p. 459.

Bitton, G. (1994). Waste Water Microbiology. Gainesvill, New York Wiley-Liss, p. 118.

Buchanan, R.E. and N.E. Gibbons, (1974). Bergey's Manual of Determinative Bacteriology. $8^{\text {th }}$ ed. The Williams and Wilkins Co., Baltimore, p. 124.

Environmental Protection Agency US (US-EPA) (2002). Safe Drinking Water Act Amendment. http://www.epa. gov/safe/mcl/Html.

Fathi, A.A., H.M.A. Abdelzaher, R.J. Flower, M. Ramdani, M.M. Kraïem, (2001). Phytoplankton communities of North African wetland lakes: the CASSARINA Project. Aquatic Ecol., 35: 303318.

FWPCA (Federal Water Pollution Control Administration), (1968). Water Quality Criteria: Report of the National Technical Advisory Committee to the Secretary of the Interior. U.S. coastal Cities: FWPCA, p. 32-34

Iskandar, M.B. (2010). The effectiveness of biofilter as a treatment for domestic wastewater. University Malaysia Pahang (thesis). 
Krishnan, R.R, K. Dharmaraj and B.D.R. Kumari, (2007). A comparative study on the physicochemical and bacterial analysis of drinking bore well and sewage water in the three different places of Sivakasi. J. Environ. Biol. 28(1): 105-108.

Mahananda, M.R. (2010). "Physico-Chemical analysis of surface water and ground water of Bargarh District, Orissa, India." Inter. J. Res. Review in Appl. Sci. 2(3): 284-295.

Mane, V.R., A.A. Chandorkar and R. Kumar, (2005). Prevalence of pollution in surface and ground water sources in the rural areas of Satara Region. Asian J. Water Environ. Pollut. 2: 81-87

Omezuruike, O.I., A.O. Damilola., O.T. Adeola., A. Enobong and B.S. Olufunke, (2008). Microbiological and physicochemical analysis of different water samples used for domestic purposes in Abeokuta and Ojota, Lagos State, Nigeria. Afri. J. of Biotech. 7 (5): 617-621.
Okpokwasili, G.C. and T. C. Akujobi, (1996). Bacteriological indicators of tropical water quality. Environ. Toxicol. Water Quality. 11: 7781.

Osunide, M. I. and N.P. Eneuzie, (1999). Bacteriological analysis of ground water. Nig. J. Microbiol. 13: 47-54.

Richman, M. (1997). Industrial Water Pollution. Wastewater. 5(2): 24-29.

Tebutt, T.H.Y. (1983). Principles of Quality Control Pergamon. England, p. 235.

Sandy, C. and F. Richard, (1995). Quality and Standard for Drinking Water Chapter 3 Environmental Health Engineering in the Tropics. And Introductory Textbook Wiley Inter Science. $2^{\text {nd }}$ ed. ISBN 0471938858, p. 294.

WHO, (1999). Guidelines for Drinking Water Quality.2 ${ }^{\text {nd }}$ ed. Geneva: WHO. 